\section{Anesthesia in Patients with Positive Direct Coombs Test. Report of Three Cases}

Joana Patrícia dos Santos Carvalho, M.D., Dora Lopes Castelo Branco Catre, M.D., Cláudia Margarida Brito Pereira, M.D., Marina Costa, M.D.

\section{INTRODUCTION}

Autoimmune hemolytic anemia ( $\mathrm{AHA}$ ) is caused by the presence of non-specific and identifiable antibodies that react with antigens on the surface of red blood cells. Anemia develops when the percentage of red blood cells destroyed exceeds the regenerative capacity of the bone marrow. In autoimmune hemolysis, autoantibodies coating the red blood cells do not damage them, but they cause hemolysis by activating complement, inducing interactions with the mononuclear phagocytic system.

Neoplastic disease can be associated with autoimmune hemolytic anemia (AHA), with consequent blood incompatibility that hinders blood transfusion in those patients ${ }^{1}$.

The nature of the clinical evolution of $\mathrm{AHA}$ and treatment modalities includes therapeutic transfusions ${ }^{2}$.

Coombs test or Direct Antiglobulin Test (DAT) represents an elementary and simple in vivo test to demonstrate the presence of $\mathrm{lgG}$ and/or complement coating the surface of erythrocytes. The use of DAT is more appropriate in hemolytic anemia when an autoimmune origin is suspected. Positive DAT has an elevated predictive value of autoimmune origin in a patient with hemolytic anemia. However, a positive DAT does not necessarily mean that an individual has hemolytic anemia and, at times, it is positive in individuals histologically normal ${ }^{3}$.

In patients with $\mathrm{AHA}$, which is defined by the short life of red blood cells due to the autoimmune humoral response associated with a positive DAT, alloantibodies and, probably, autoantibodies, hinder the determination of compatibility when blood transfusions are necessary. In those patients, blood transfusions can be disastrous and cause severe deleterious effects ${ }^{3}$.

The objective of this study was to report and discuss the conduct in three patients with positive direct Coombs Test (CT) and the impossibility to determine their blood group for surgical interventions for neoplastic disease.

\section{CASE REPORT}

Table I summarizes the evolution and the approach of the three cases.

\section{CASE 1}

A 78-year old male patient previously healthy, without any history of prior transfusions or anesthetic-surgical procedures.
The patient was scheduled for exploratory laparotomy for a colon neoplasia. Clinically, the patient had anemia (hemoglobin 8.8 g.dL-1) with positive DAT (lg3+), which made it impossible to determine his blood type. He was treated with iron, erythropoietin, immunoglobulin, and corticoids, and after five days we were able to determine his blood type, O Rh negative. He was classified as ASA III.

The surgery (colostomy) was performed under general balanced anesthesia lasting 60 minutes. One unit of packed-red blood cells (PRBC) was transfused due to blood loss with hemodynamic instability. Post-transfusional exams showed hemoglobin of 9.0 g. dL ${ }^{-1}$. The patient remained hemodynamically stable during the 120 minutes he stayed in the PostAnesthetic Care Unit (PACU).

In the ward, four hours after discharge from the PACU, the patient became comatose (Glasgow 4) associated with worsening of the anemia (hemoglobin 7.0 g.dL-1 The patient died 24 hours after the surgery with a diagnosis of an ischemic stroke.

\section{CASE 2}

A 77-year old male patient without history of blood transfusions or anesthetic-surgical procedures, scheduled for gastrectomy for an adenocarcinoma of the stomach.

The patient had atrial fibrillation (AF) and hypertension (HTN), clinically controlled. He was classified as ASA III.

Laboratorial tests showed hemoglobin $(\mathrm{Hb})$ at $14.0 \mathrm{~g} . \mathrm{dL}^{-1}$ and thrombocytopenia with $55 \times 10^{9}$ platelets. $\mathrm{L}^{-1}$. Since he had a positive DAT (Ig4+), he was treated with corticoids and immunoglobulin for 25 days, but we were unable to determine his blood type.

The patient underwent general balanced anesthesia, and during the surgery he received six units of platelets due to intraoperative venous bleeding. The surgery lasted 150 minutes.

The patient remained stable during his stay in the PACU (120 minutes), and laboratorial exams showed hemoglobin 12.8 g.dL ${ }^{-1}$ and $80 \times 10^{9}$ platelets. $\mathrm{L}^{-1}$.

On the $9^{\text {th }}$ postoperative day, his hemoglobin fell to $8.5 \mathrm{~g} . \mathrm{dL}^{-1}$ with thrombocytopenia of $20 \times 10^{9}$ platelets. $L^{-1}$, and he received five units of platelets.

The patient died on the $18^{\text {th }}$ postoperative day due to worsening of his medical condition.

\section{CASE 3}

An 80-year old female patient with the diagnosis of acute abdomen who underwent emergency exploratory laparotomy.

The patient had a history of ischemic cardiopathy, AF, and HTN all treated clinically. Three weeks before admission, she received three units of PRBC for anemia, with $\mathrm{Hb} 7.2$ g.dL-1. She was classified as ASA IV.

Upon admission, the patient had several complaints and she had signs of poor peripheral perfusion and tachycardia secondary to AF (140 bpm), which was controlled with amio- 
Table I - Evolution and Approach of the Three Cases

\begin{tabular}{|c|c|c|c|}
\hline & Case 1 & Case 2 & Case 3 \\
\hline Surgical intervention & Elective colostomy & Elective gastrectomy & Emergency hemicolectomy \\
\hline Clinical presentation & Anemia & AF, HTN & Ischemic cardiopathy, AF, HTN, CRF, anemia \\
\hline Preoperative laboratorial exams & $\begin{array}{l}\mathrm{Hb} 8.8 \mathrm{~g}_{\mathrm{dL}}^{-1} \\
\text { DAT } \lg 3+\end{array}$ & $\begin{array}{l}\mathrm{Hb} 14.0 \mathrm{~g} \cdot \mathrm{dL}^{-1} \\
\text { DAT } \lg 4+\end{array}$ & $\begin{array}{l}\mathrm{Hb} 9.0 \mathrm{~g}^{-\mathrm{dL}^{-1}} \\
\text { DAT } \lg 4+\end{array}$ \\
\hline Treatment & \multicolumn{3}{|c|}{ Corticoids, immunoglobulin, iron, erythropoietin } \\
\hline Blood type & O Rh positive & Blood type not available & Blood type not available \\
\hline \multicolumn{4}{|l|}{ Transfusion } \\
\hline Preoperative & - & - & 3 units of PRBC \\
\hline Perioperative & 1 unit PRBC & 6 units of platelets & - \\
\hline Postoperative & - & 5 units of platelets & - \\
\hline Postoperative laboratorial exams & $\mathrm{Hb} 7.0 \mathrm{~g} \cdot \mathrm{dL}^{-1}$ & 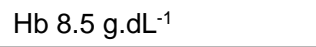 & $\mathrm{Hb} 7.7 \mathrm{~g} \cdot \mathrm{dL}^{-1}$ \\
\hline Postoperative period & $\begin{array}{l}\text { Ischemic stroke } \\
\text { Died } 24 \text { hours post-surgery }\end{array}$ & $\begin{array}{l}\text { Shock } \\
\text { Died on the } 18^{\text {th }} \text { day }\end{array}$ & $\begin{array}{l}\text { Ischemic stroke } \\
\text { Died } 48 \text { hours post-surgery }\end{array}$ \\
\hline
\end{tabular}

$\mathrm{DAT}=$ direct antiglobulin test (Coombs); $\mathrm{AF}=$ atrial fibrillation; $\mathrm{CRF}=$ chronic renal failure; $\mathrm{HTN}=$ hypertension; $\mathrm{Hb}=$ hemoglobin; $\mathrm{PRBC}=$ packed-red blood cells .

Chart I - Causes of Positive Direct Antiglobulin Test (Coombs)

\begin{tabular}{|c|c|c|c|}
\hline \multicolumn{4}{|c|}{ Hemolysis } \\
\hline Alloimmune & Autoimmune & Drug-induced & Other \\
\hline $\begin{array}{l}\text { - Hemolytic Disease } \\
\text { of the Newborn } \\
\text { - Post-transfusional } \\
\text { hemolytic reactions }\end{array}$ & $\begin{array}{l}\text { - Idiopathic } \\
\text { - Systemic lupus erythematosus } \\
\text { - Evans syndrome } \\
\text { - Infectious mononucleosis } \\
\text { - Paroxysmal cold hemoglobinuria } \\
\text { - Lympho- and myeloproliferative neoplasia: } \\
\text { chronic lymphocytic leukemia and B cell } \\
\text { lymphoma } \\
\text { - Organ and hematopoietic cell transplant } \\
\text { - Acute leukemia (rare) } \\
\text { - Hodgkin's disease, non-Hodgkin lymphoma } \\
\text { - Waldenström macroglobulinemia } \\
\text { - Multiple myeloma } \\
\text { - Angioimmunoblastic lymphadenopathy } \\
\text { - Solid tumors (carcinoma): ovary, breast, } \\
\text { lung, colon, pancreas, kidneys, thymus, uterus, } \\
\text { testicles } \\
\text { - Kaposi sarcoma }\end{array}$ & $\begin{array}{l}\text { - Alpha-methyldopa } \\
\text { - Penicillin } \\
\text { - Quinidine } \\
\text { - Procainamide } \\
\text { - Purine analogues } \\
\text { - Isoniazid } \\
\text { - Cephalosporins } \\
\text { - Tetracyclines } \\
\text { - Sulfonamides } \\
\text { - Streptomycin } \\
\text { - Rifampin } \\
\text { - Ampicillin } \\
\text { - Antihistamines } \\
\text { - Insulin } \\
\text { - Ibuprofen } \\
\text { - L-dopa } \\
\text { - Acetaminophen }\end{array}$ & $\begin{array}{l}\text { - Technical factors } \\
\text { (procedures used for the } \\
\text { collection and storage of the } \\
\text { sample) } \\
\text { - Sensitivity of the method } \\
\text { used (tube, gel, solid phase, } \\
\text { etc.) }\end{array}$ \\
\hline
\end{tabular}

darone and digitalis. Laboratorial tests showed anemia with $\mathrm{Hb} 9.0$ g.dL, renal failure (BUN $57 \mathrm{mg} \cdot \mathrm{dL}^{-1}$ and creatinine 1.9 $\left.\mathrm{mg} \cdot \mathrm{dL}^{-1}\right)$, and positive DAT (lg4+), and we were unable to determine her blood type.

The patient underwent a hemicolectomy (due to an obstructive tumor in the colon) under general balanced anesthesia that lasted 150 minutes. She remained hemodynamically stable during surgery. Postoperative laboratorial tests revealed $\mathrm{Hb}$ $7.7 \mathrm{~g} \cdot \mathrm{dL}^{-1}$, but she was not transfused.

The patient remained stable during her stay in the PACU for three and a half hours. When she was transferred to the ward she was conscious, but collaborating minimally.

She died 48 hours after the surgery from an ischemic stroke.

\section{DISCUSSION}

Autoimmune hemolytic anemia ( $\mathrm{AHA})$ is frequently idiopathic and it can be a complication of neoplasias. Its incidence is difficult to evaluate because minimal amounts of erythrocyte immunoglobulins can be undetectable without special techniques, and post-transfusional isoimmunization can hinder the diagnosis of AHA.

However, AHA is a well-characterized disease whose diagnosis is based on demonstrating the presence of hemolysis, which leads to variable degrees of anemia, and the autoimmune characteristic of this destruction. The presence of hemolysis, defined as a reduction in the survival of erythrocytes, can be demonstrated by indirect methods, such as simple laboratorial 
tests: serum levels of total and conjugated bilirubin, lactate dehydrogenase (LDH), haptoglobin, and CBC, including reticulocyte count and peripheral blood smear.

Direct antiglobulin test has a high predictive value regarding the autoimmune etiology of hemolytic anemia. However, cases of AHA with negative DAT have been described ${ }^{3}$.

The same way the absence of a positive DAT does not exclude the presence of AHA, a positive test, even in the presence of anemia that can result from multiple causes, should not be considered synonymous of this disorder. Direct antiglobulin test can be positive in patients with infections, under treatment with different drugs, or it might have an unknown clinical significance. When autoantibodies with a reactivity pattern similar to that of AHA are detected, but without evidence of hemolysis, other factors that interfere with the activity of the macrophage system are most likely involved. One hypothesis would be the depression in the phagocytic activity of the macrophage system leading to the presence of a level of autoantibodies that can be detected in vitro, but which does not have the capacity to cause hemolysis. The use of immunosuppressors, especially corticosteroids; and the presence of autoimmune disorders, such as systemic lupus erythematosus, in which the presence of large amounts of circulating immune complexes can saturate macrophage receptors stopping them from effectively removing erythrocytes from circulation are examples of this hypothesis. However, those antibodies can be found in healthy individuals, especially blood donors, without known diseases. Positivity can remain indefinitely, without any clinical significance, revert, or in a small number of cases it can evolve to $\mathrm{AHA}^{3}$.

Half of the cases of AHA secondary to neoplasia originate from lymphoproliferative disorders, especially of B cells (chronic lymphocytic leukemia and lymphomas). But other neoplasias can be associated with this type of anemia ${ }^{2,4}$ (Chart I).

Repeated transfusions can increase the risk of alloimmune response, and AHA is a potential complication of allogeneic blood transfusion that develops concomitantly or shortly after the transfusion. In those cases, supportive treatment with iron and erythropoietin, avoiding blood transfusion whenever possible, is recommended ${ }^{4,5}$.

Unfortunately, the preparation and selection processes of blood for patients with AHA is slow, intensive, complicated, and expensive, and it is very difficult to find compatible blood even when a specificity is found. Usually, in emergency cases in which there is no time to undertake serology testing the best a blood bank can do is to offer units of PRBC that are more compatible with the blood of the patient, even though those units might not survive in the circulation. However, the ideal would be to transfuse blood compatible with the blood group of the patient, except in those rare situations in which the patient has $A$ or $B$ antigen-specific autoantibodies, when $O$ blood should be transfused.

The decision to transfuse should not be solely based on hemoglobin levels. Clinical evaluation has an important role when hemoglobin levels range from 5 to $8 \mathrm{~g} \cdot \mathrm{dL}^{-1}$. In this interval, many patients with AHA should be transfused, unless the patient is hemodynamically stable and progression of anemia is not evident. Below $5 \mathrm{~g} \cdot \mathrm{dL}^{-1}$, the majority of patients need to be transfused 6 .

Transfusion is indicated for patients with AHA who are at high risk of brain or cardiovascular ischemia, even when it is not possible to determine their blood type.

Thus, a patient with AHA should be transfused whenever he/ she is at risk for anemia-related cardiovascular compromise considering the following additional risk factors: age, history of cardiovascular disease, blood loss, and aggressive hemolysis. Note that those patients are usually normovolemic and, therefore, signs of cardiovascular decompensation might not be perceptible unless they are carefully evaluated.

Although survival of transfused erythrocytes is decreased, severe hemolytic transfusional reactions are rare. Nonetheless, caution should be used when transfusing a patient with $\mathrm{AHA}$, weighing the risks and benefits individually. According to some authors, the risks of blood transfusion in AHA, besides those inherent to this treatment modality, are related with the increase in antigenic load and consequent increase in antigenic stimulus, potentiating the reactivity of the antibody and decreasing the response to corticosteroids, and the risk of alloimmunization is higher in those patients ${ }^{3}$.

The minimal volume possible to decrease the symptoms of anemia should be transfused. Some authors recommend the transfusion of small volumes, just enough to relieve symptoms, without the need to correct hemoglobin levels. This avoids volume overload, in the case of normovolemic patients, and, on the other hand, in case of transfusional hemolytic reaction it avoids the complications related with hemolysis of a large volume of erythrocytes, such as renal failure or disseminated intravascular coagulation ${ }^{3}$.

Transfusion of platelets and other plasma products should also be compatible with the patient blood type, minimizing hemolytic reactions. Kidney function should always be evaluated due to the risk of renal failure associated with intravascular hemolysis.

Autoimmune hemolytic anemia does not have a cure. As a secondary disorder, patients should be evaluated for the presence of other immune disorders. If detected, treatment of the baseline disorder frequently corrects AHA. Standard treatment includes corticosteroids, splenectomy, and immunosuppressors.

In the cases presented here, the correlated diseases of our patients are associated with high perioperative morbimortality. This risk might have been aggravated by possible transfusional reaction (although in the $2^{\text {nd }}$ case the diagnosis was not confirmed) or by the effects of anemia (probably in the $1^{\text {st }}$ and $3^{\text {rd }}$ cases) that might have contributed for the fatal evolution.

Although immunosuppressor treatment was instituted in the first two cases before the surgery, the blood type was determined only in the first case. And although this patient was hemodynamically stable, he received one unit of PRBC perioperatively due to the blood loss during the surgery and the consequent evidence of the progression of preexisting anemia. In the second case, although we were not able to determine the blood type, transfusion of 11 units of platelet was 
justified by the baseline thrombocytopenia associated with the conditions of the surgery, perioperative hemorrhage, and progression of thrombocytopenia.

In the third case, the emergency factor increased the risk. The impossibility of determining the blood type of the patient before the surgery, along with pre- and postoperative hemodynamic stability, was responsible for the decision of not transfusing her. The decision of whether to transfuse or not patients with AHA remains controversial.

In patients with $\mathrm{AHA}$, repeated transfusions increase the risk of alloimmune response and circulating antibodies can destroy transfused cells as fast as they destroy the erythrocytes of the patient, and post-transfusional hemolytic reactions are expected. For this reason, some authors defend that the risk of transfusing those patients is higher than the temporary benefits of the transfusion?.

However, other authors argue that transfusions do not exacerbate hemolysis or alloimmuniaztion and, if incompatibility results only from the presence of autoantibodies against erythrocytes, acute reactions are rare and the survival of transfused erythrocytes is virtually similar to that of the own red blood cells of the patient, therefore resulting in significant temporary benefits from the transfusion ${ }^{8}$.

Therefore, the indications for blood transfusion in patients with AHA do not differ from those of anemic patients without AHA, as long as proper compatibility procedures to detect and identify the alloantibodies of erythrocytes are followed.

Patients without a history of transfusions have a low probability of having alloantibodies. In fact, only a small percentage of hospitalized patients have alloantibodies and, if the transfusion is considered urgent, the risk of transfusion is lower than expected from the compatibility determination tests ${ }^{6}$.

However, the decision to transfuse implies communication between the physician, who evaluates the clinical need to transfuse, and the immunohemotherapy service, that identifies alloantibodies that can trigger a post-transfusional hemolytic reaction, in face of the benefits of the transfusion.

Even though immunosuppressive therapy allows the determination of the blood type, the decision to transfuse blood products should consider the high risk of hemolysis in those patients.

Patients who have diseases associated with AHA and positive DAT are at a higher risk of developing post-transfusional hemolysis due to the presence of non-identifiable alloantibodies on red blood cells, making transfusion a complex and risky therapeutic measure. In patients with severe AHA, blood should be cautiously transfused and for appropriate indications. Those patients should have a multidisciplinary approach involving the patient, surgeon, anesthesiologist, and immunotherapist for the identification and possible remission of existing autoantibodies, and the adoption of blood-sparing strategies. The decision to transfuse should consider the needs of the patient, as well as the risks and potential benefits of alternative therapy.

In case of emergencies and blood typing is not possible, the procedure should be a life-saving blood transfusion'.

\section{REFERÊNCIAS - REFERENCES}

1. King KE, Ness PM. Treatment of autoimmune hemolytic anemia. Semin Hematol 2005;42:131-136.

2. Narvios A, Lichtiger B. Blood transfusion in patients having hematologic malignancies and solid tumors: problems associated with AlHA and unidentifiable RBC alloantibodies. Curr Issues Transfus Med 2001. Disponível em http://www3.mdanderson.org/ citm/H-01-09. html

3. Duran JA, Rodrigues MJ. Teste de antiglobulina directo: ausência de significado clínico como teste pré-transfusional. ABO Rev Med Transf 2000;(1):15-17.

4. Hoffman PC. Immune hemolytic anemia: selected topics. Hematology Am Soc Hematol Educ Program 2006:13-18.

5. Young PP, Uzieblo A, Trulock E et al. Autoantibody formation after alloimmunization: are blood transfusions a risk factor for autoimmune hemolytic anemia? Transfusion 2004;44:67-72.

6. Petz LD. Emergency transfusion guidelines for autoimune hemolytic anemia. Lab Medicine 2005;36:45-48.

7. Smith LA. Autoimmune hemolytic anemias: characteristics and classification. Clin Lab Sci 1999;12:110-114.

8. Petz LD, Garratty G. Immune Hemolytic Anemias, 2nd Ed. New York: Churchill Livingstone, 2004;224.

9. Garratty G, Petz LD. Approaches to selecting blood for transfusion to patients with autoimmune hemolytic anemia. Transfusion 2002;42:1390-1392.

\section{RESUMEN}

Carvalho JPS, Catré DLCB, Pereira CMB, Costa M - Anestesia en Pacientes con Test de Coombs Directo Positivo. Relato de Tres Casos

JUSTIFICATIVA Y OBJETIVOS: Existe una asociación entre las anemias hemolíticas autoinmunes (AHA) y la enfermedad neoplásica, con la consecuente incompatibilidad sanguínea que dificulta la transfusión de esos pacientes. Los autores describen y discuten la conducta en tres casos propuestos para la intervención quirúrgica por una enfermedad neoplásica, con el Test de Coombs Directo (TCD), positivo y la imposibilidad de la determinación de un grupo sanguíneo.

RELATO DE LOS CASOS: 1ํaso: paciente del sexo masculino, 87 años, ASA III, listo para la intervención quirúrgica por neoplasia del colon. Presentó un TCD positivo, fue tratado con corticoide, inmunoglobulina (Ig) y eritropoyetina, siendo posible la tipificación. En el intraoperatorio, se administró una unidad de concentrado eritrocitario (UCE) sin incidentes. La El paciente falleció 24 horas después por accidente vascular encefálico isquémico. 2ํㅜ caso: paciente del sexo masculino, 77 años, ASA III, listo para intervención quirúrgica de carcinoma gástrico. Presentó un TCD positivo, realizó tratamiento con corticoide e lg, sin haber logrado la tipificación. La intervención quirúrgica transcurrió sin incidentes. Falleció al 18o día del postoperatorio, después de una parada cardiorrespiratoria. $3^{\circ}$ caso: paciente del sexo femenino, 80 años, ASA IV, para laparotomía exploradora de urgencia. También presentó un TCD positivo. La intervención quirúrgica (hemicolectomía), transcurrió sin incidentes. Falleció a las 48 horas del postoperatorio con un accidente vascular encefálico isquémico.

CONCLUSIONES: Los autoanticuerpos (Ac) circulantes en las AHA, pueden imposibilitar la tipificación sanguínea y la disponibilidad de sangre compatible para la transfusión. El tratamiento correcto de la AHA, tiene el objetivo de alcanzar la remisión de los Ac y de realizar el tratamiento de la anemia. Si tenemos la urgencia de transfundir sin la posibilidad de tipificar, la transfusión sanguínea surge como una medida life-saving. (economía de vida). 